PUSTABIBLIA: Journal of Library and Information Science

ISSN 2549-3493 (Print); ISSN 2549-3868 (Online)

DOI: http://dx.doi.org/10.18326/pustabiblia.v3i2.189-203

SK Dirjen Risbang-Kemristekdikti No 23/E/KPT/2019 (Peringkat 4 SINTA)

\title{
Upaya Perpustakaan Perguruan Tinggi dalam Mewujudkan Integritas Akademik
}

\author{
Kurnia Sholihah ${ }^{1^{*}}$, Sri Sulastri ${ }^{2^{*}}$ \\ ${ }^{1}$ Universitas Agung Podomoro \\ ${ }^{2}$ Universitas Agung Podomoro \\ ^Kurnia.sholihah@podomorouniversity.ac.id, Sri.sulastri@ \\ podomorouniversity.ac.id
}

\begin{abstract}
Every unit in higher education institution have a responsibility to maintain their academic integrity. Being dishonest by claiming other people's work (plagiarism) in a scientific work, is a violation to academic integrity and may be punished according to State Law Act. 20 Year 2003 about National Education System. The Sanction is revocation of academic title, or worst, criminal law act. Library has a function, which is to disseminate the scientific works result, and it holds important role to maintain the originality of the content. The purpose of this paper is to examine the efforts that library can do to maintain the academic integrity with a literature study method. Library can do many things to maintain academic integrity, such as: contributing to ethic's team, integrating information literacy program into the curriculum, having a policy to prevent plagiarism, doing an anti plagiarism campaign, using a tools to detect plagiarism, and providing adequate references. Those ways have to be done continuously and being synergized with all the units, so that the academic integrity can be a culture for academic community..
\end{abstract}

\section{Abstrak}

Upaya terwujudnya integritas akademik merupakan tanggung jawab dari setiap unit di Perguruan tinggi. Hal ini pun berlaku bagi perpustakaan, yang berperan sebagai unit desiminasi hasil karya ilmiah yang memiliki tantangan tersendiri agar karya yang dipublikasikan merupakan karya yang orisinil bebas dari plagiat. Ketidakjujuran mengakui karya orang lain dalam hal ini plagiat, merupakan pelanggaran terhadap integritas akademik yang dapat dikenakan sanksi hukuman sesuai Undang- 
Undang No. 20 tahun 2003 tentang sistem pendidikan nasional yaitu mulai dari pencabutan gelar akademik, hingga hukuman pidana. Tujuan penulisan ini adalah untuk mengkaji tentang upaya yang dapat dilakukan perpustakan dalam menjaga integritas akademik yang dikaji menggunakan metode studi literatur. Upaya yang dapat dilakukan perpustakaan dalam menjaga integritas akademik antara lain: pembentukan tim etika, integrasi program literasi informasi kedalam kurikulum perkuliahan, kebijakan pencegahan tindakan plagiat, sosialisasi anti plagiat, penggunaan alat deteksi plagiat dan penyediaan referensi yang memadai. Upaya-upaya tersebut perlu dilakukan berkesinambungan dan bersinergi dengan seluruh unit supaya kejujuran akademik sebagai budaya sivitas akademik dapat terwujud.

Keywords: Integritas Akademik; Plagiat; Perpustakaan Perguruan Tinggi.

\section{Pendahuluan}

Perguruan tinggi merupakan inkubator ilmu pengetahuan yang menghasilkan berbagai jenis luaran ilmiah. Luaran ilmiah ini, akan menjadi representasi keilmuan Perguruan Tinggi yang perlu dijamin kualitasnya. Esensi kualitas pendidikan, tidak akan lepas dari sisi kecerdasan intelektual peserta didiknya dan juga kejujuran intelektual dalam mencapai tujuan akademis. Sikap jujur yang sudah menjadi habit, merupakan bekal bagi peserta didik untuk mengabdi dan mengamalkan ilmunya dalam berbangsa dan bernegara kelak. Budaya akademik yang menjunjung tinggi nilai-nilai kejujuran bukanlah perkara mudah untuk diwujudkan. Hal ini terjadi karena masih maraknya perilaku-perilaku yang disadari atau tidak telah mengkhianati nilai-nilai kejujuran itu sendiri.

Terdapat penelitian membuktikan bahwa masih banyak perilaku tidak jujur yang sering terjadi pada mahasiswa yaitu menyontek, plagiat, atau melanggar aturan perkuliahan. ${ }^{1}$ Kurangnya kesadaran mahasiswa akan pentingnya berperilaku jujur menunjukkan kurangnya integritas akademik suatu perguruan tinggi. Menurut Jones, integritas akademik merupakan prinsip seseorang dalam mematuhi serangkaian etika akademis. Integritas

${ }^{1}$ Fiska Puspa Arinda, "Ketidakjujuran Akademik Mahasiswa Perguruan Tinggi X Di Surakarta”, (Skripsi, Universitas Muhammadiyah Surakarta, 2015) http://eprints.ums. ac.id/34416/1/02.\%20NASKAH\%20PUBLIKASI.pdf. 
akademik perlu dibudayakan sejak dini agar mahaiswa terbiasa berperilaku jujur, menghargai kode etik perguruan tinggi, dan bertanggung jawab atas segala aktivitas akademis. ${ }^{2}$ Pembudayaan interitas akademik akan berhasil jika seluruh elemen siviats akademik ikut berpartisipasi.

Upaya terwujudnya integritas akademik merupakan tanggung jawab dari setiap unit di perguruan tinggi. Hal ini pun berlaku bagi perpustakaan, yang berperan sebagai unit desiminasi hasil karya ilmiah yang memiliki tantangan tersendiri agar karya yang dipublikasikan merupakan karya yang orisinil bebas dari plagiat. Kemudahan akses informasi melalui internet menjadi salah satu pemicu mahasiswa maupun dosen sangat rentan terjebak pada perilaku copy paste. Sebagai insan akademik yang beretika sudah seharusnya mahasiswa memiliki penghargaan atas ide orang lain dengan mencantumkan sumber asli dari sebuah referensi pada karya ilmiahnya.

Selain itu, pola perilaku pencariaan informasi secara online membutuhkan kemampuan penelusuran dan evaluasi informasi. Pengutipan sumber referensi yang tidak benar akan mengarahkan mahasiswa terhadap tindakan penyajian data yang tidak bisa dipertanggung jawabkan. Sehingga, kemampuan sitasi ini sangat dibutuhkan setiap mahasiswa agar dapat menuliskan sumber referensi sesuai kaidah penulisan yang baik dan benar. Pentingnya sumber informasi yang valid menjadi tangung jawab perpustakaan agar sumber referensi yang digunakaan mahasiswa benar-benar kredibel.

Permasalahan-permasalahan yang berkaitan dengan plagiarisme ini, memiliki beberapa alasan diantaranya kurangnya informasi mengenai jenisjenis plagiarisme dan cara mengutip yang benar. ${ }^{3}$ Selain itu, faktor penyebab plagiat dibedakan menjadi dua yaitu secara sengaja dan tidak sengaja. Ketidaksengajaan plagiarisme dipengaruhi karena faktor waktu yang terbatas dalam menyelesaikan tugas, keterampilan menulis yang kurang, anggapan bahwa dosen tidak akan memperdulikan sitasi pada tugas, hingga upaya menghindari pengetahuan tentang plagiarisme. Plagiarisme secara sengaja

\footnotetext{
${ }^{2}$ Lars R Jones, Academic Integrity \& Academic Dishonesty: A Handbook About Cheating \& Plagiarism (Florida: Floride Institude of Technology, 2011), 3, http://hdl.handle.net/11141/2601.

${ }^{3}$ Fiska Puspa Arinda, "Ketidakjujuran Akademik ....13.
} 
dapat terjadi karena mengakui ide atau tulisan orang lain sebagai tulisan pribadi. Contoh lain yang paling fatal terjadi yaitu adanya jasa joki penulisan. ${ }^{4}$ Tindakan plagiat tersebut menunjukkan sikap mahasiswa yang tidak mau berfikir dan berusaha terhadap beban akademik yang harus diselesaikan.

Ketidakjujuran mengakui karya orang lain dalam hal ini plagiat, merupakan pelanggaran terhadap integritas akademik yang dapat dikenakan sanksi hukuman sesuai Undang-Undang No. 20 tahun 2003 tentang sistem pendidikan nasional yaitu mulai dari pencabutan gelar akademik, hingga hukuman pidana. Peranan strategis perpustakaan dalam mencegah disentrigasi akademik mahasiswa, perlu dilakukan kajian lebih lanjut agar dapat diketahui langkah-langkah praktis dan upaya pencegahannya guna mencapai integritas akademik yang kokoh pada suatu perguruan tinggi. Tujuan penulisan ini adalah untuk mengkaji tentang upaya perpustakan dalam menjaga integritas akademik dengan menggunakan metode studi literatur yang mempelajari referensi mengenai integritas akademik dan upaya yang dapat dilakukan perpustakaan dalam menjaga integritas akademik.

\section{Tinjauan Pustaka}

\section{Integritas Akdemik}

Integritas dalam kamus bahasa Indonesia diartikan mutu, sifat, atau keadaan yang menunjukkan kesatuan yang utuh sehingga memiliki potensi dan kemampuan yang memancarkan kewibawaan; kejujuran. ${ }^{5}$ Integritas sebagai suatu sikap menjunjung tinggi adanya kejujuran yang tertanam dalam diri seseorang melalui proses yang tidak instan. Integritas perlu ditanamkaan secara berkesinambungan mulai dari keluarga hingga lembaga pendidikan formal. Dalam sebuah organisasi, Integritas akan menjadi ruh, yang menjaga kesolidan anggotanya dalam mencapai tujuan organisasi.

${ }^{4}$ Adik Wibowo, "Mencegah dan menanggulangi plagiarisme di dunia pendidikan," Jurnal Kesehatan Masyarakat Nasional, vol. 6 no. 1 (2012):195-200. http://journal.fkm.ui.ac.id/kesmas/ article/view/84/85

${ }^{5}$ Kamus Besar Bahasa Indonesia, “integritas,” akses 14 November 2019 https://kbbi.web. $\underline{\text { id/integritas }}$ 
Integritas dalam dunia pendidikan dikenal dengan istilah integritas akademik yang memiliki definisi komitmen, atas lima nilai dasar: kejujuran, kepercayaan, keadilan, rasa hormat, dan tanggung jawab. ${ }^{6}$ Integritas adalah sifat, atau keadaan yang menunjukkan kesatuan yang utuh, berpegang teguh pada prinsip dan kesesuaian antara kata dengan perbuatan. Menurut Aryani dalam Sahril ciri-ciri yang orang yang memiliki integritas tinggi:

a. Berkomitmen tinggi dalam pekerjaan, yakni mereka yang menepati janji dan keyakinan diri yang kuat, termasuk untuk tidak menyontek (plagiat).

b. Bertanggung jawab, yakni mereka yang berani mengambil resiko dan total melakukan sesuatu dengan kemampuan terbaik yang dimilikinya, termasuk bertanggung jawab untuk menyelesaikan soal/tugas dari dosen secara jujur tanpa melakukan plagiat.

c. Dapat dipercaya, jujur dan setia, yakni orang sejalan antara kata dan perbuatan, termasuk jujur dalam mengerjakan soal/tugas dari dosen tanpa harus melakukan plagiat.

d. Konsisten pada pendirian, yakni mereka yang tegas pada keputusan dan pendiriannya, dengan melakukan perimbangan yang bijak dalam bertindak dan bertingkah laku. ${ }^{7}$

Nilai-nilai di atas dapat dijadikan pedoman bagi dosen maupun mahasiswa dalam menjalankan peranan akademik. Perguruan Tinggi sebagai pencetak generasi penerus bangsa memiliki tanggung jawab untuk memberikan pendidikan moral, salah satunya sikap kejujuran. Sehingga, kepatuhan terhadap niali-nilai integritas adalah suatu kewajiban dan menjadi tugas dari Perguruan Tinggi untuk menguatkannya secara berkesinambungan. Kajian ini, membahas integritas akademik yang ditekankan pada aspek kejujuran akademik yaitu kepatuhan mahasiswa dalam jujur mengakui karya orang lain dengan tidak plagiat dalam penulisan ilmiah.

\footnotetext{
${ }^{6}$ International Center for Academic Integrity, The Fundamental Values of Academic Integrity. (Illinois: Clemson University, 2013), 16 https://academicintegrity.org/fundamental-values/

${ }^{7}$ Sahril Buchori, Muhammad Ibrahim, and Abdul Saman, "Pengaruh Character Education Training Melalui Outbound Training Untuk Peningkatan Kejujuran Dan Integritas," Jurnal Psikologi Pendidikan \& Konseling, Vol. 2 No. 1 ( 2016): 13. https://ojs.unm.ac.id/JPPK/article/view/2089
} 


\section{Bentuk Disintegritas Akademik}

Penegakan integritas akademik sudah menjadi wacana dari banyak Perguruan Tinggi, melalui penanaman nilai nilai integritas seperti kejujuran, komitmen, bertanggung jawab, dapat dipercaya, dan konsisten. Perbuatan yang melanggar nilia nilai tersebut menjadi bentuk disintegrasi akademik. Menurut Carter dalam Abid, bentuk bentuk pelanggaran terhadap integritas yang kerap terjadi dalam dunia pendidikan antara lain:

a. Plagiarisme: pemakaian bahasa dan pemikiran orang lain secara tidak sah dan merepresentasikannya sebagai miliknya.

b. Cheating: perilaku yang bertentangan dengan aturan tes; perilaku yang memberikan kesempatan dan keuntungan kepada peserta tes/ujian yang tidak fair lewat peserta tes yang lain;

c. Fabrication: manipulasi informasi dan situasi/pengutipan dalam tes akademik.

d. Falsification: memanipulasi data penelitian dan proses; merubah atau menghapus data atau hasil penelitian untuk menunjukkan bahwa penelitian tertentu salah;

e. Facilition academic dishonesty: secara sengaja membantu dan memfasilitasi orang lain untuk melakukan ketidakjujuran akademik. ${ }^{8}$

\section{Hasil dan Pembahasan}

Upaya Perpustakaan dalam Mewujudkan Integritas Akademik

\section{a. Pembentukan Tim Etika}

Perguruan tinggi dalam mewujudkan terselenggaranya pendidikan, penelitian dan pengabdian masyarakat, senantiasa menjunjung nilai nilai dan norma norma agar tercipta iklim akademis yang kondusif. Sehingga, perlu dibentuk tim etika atau majelis kode etik sebagi pihak yang berwenang dalam menegakkan dan menangani masalah etika, moral dan disiplin sivitas

${ }^{8}$ Abid Rohmanu, “Tata Kelola Mahasiswa Terhadap Integritas Akademik Dan Plagiarisme,” Muslim Heritage Vol. 1 No. 2 (2016): 335. http://jurnal.iainponorogo.ac.id/index.php/muslimheritage/ article/view/603 
akademik. Hal ini di ataur dalam Peraturan Menteri Ristek Dikti Nomor 54 tahun 2016 Pasal 12 bahwa Pemimpin Perguruan Tinggi membentuk Majelis kode etik ditingkat pendidikan tinggi paling sedikit 3 orang anggota yang diangkat berdasarkan surat keputusan pejabat berwenang. ${ }^{9}$ Tim etika dalam menunjang tugasnnya memiliki pedoman kode etik yang berisi ketentuan atas nilai dan etika yang harus dipatuhi baik dosen, tenaga kependidikan maupun mahasiswa.

Kode etik suatu perguruan tinggi idealnya mengatur etika secara menyuluruh yang dapat diaplikasikan sivitas akdemik dalam pengamalan Tri Dharma Perguruan Tinggi. Kode etik sebagai rambu rambu dalam berperilaku memiliki asas yang tidak lepas dari nilai integritas yang menjunjung tinggi nilai kejujuran, bertanggung jawab, dan disiplin. Hal ini dapat dilihat pada pengamalan penelitian, terdapat penekanan khusus kode etik ilmiah yang mengatur ketentuan untuk menghindari adanya tindakan disentrigarsi akademik seperti plagiat, fabrikasi, falsifikasi dan ketidakjujuran akademik lainnya.

Upaya memerangi plagiat merupakan agenda bersama khususnya Perpustakan Perguruan Tinggi sebagai pusat desiminasi hasil karya ilmiah. Semua aktivitas desiminasi harus sesuai dengan nilai nilai kode etik ilmiah sehingga perpustakan diharapkan berkontribusi dalam upaya penegakan kode etik kejujuran ilmiah. Perpustakan harus mampu menjadi pihak yang dipercaya dalam menegakkan kejujuran ilmiah terhadap hasil karya ilmiah. Penerapan kode etik harus benar-benar mengatur sedetail mungkin kemungkinan munculnya perilaku disintegrasi dalam publikasi karya ilmiah seperti plagiat, fabrikasi, falsifikasi atau kecurangan-kecurangan lainnya, sehingga perpustakaan dapat berkontribusi dalam perumusan kode etik yang fokus dalam kajian perilaku disintregasi akademik dalam penelitian dan publikasi karya ilmiah.

Peran strategis lain pihak perpustakaan yaitu berkontribusi sebagai pihak investigasi terhadap hasil karya ilmiah yang akan dipublikasi.

${ }^{9}$ Peraturan Menteri Ristek Dikti Nomor 54 tahun 2016, Menteri Riset, Teknologi, Dan Pendidikan Tinggi (Jakarta, 2016). 
Perpustakan sebagai bagian dari tim etika dapat berperan dalam melindungi dan menjaga hasil karya agar tidak sampai melanggar kode etik ilmiah. Sungguh suatu aib jika terdapat hasil karya ilmiah pada suatu Perguruan Tinggi terkuak di ranah publik. Sehingga setiap publikasi haruslah melewati investagi pihak perpustakaan apakah hasil karya benar-benar tidak melanggar kode etik penelitian.

Langkah preventif perpustakan sebagai bagian dari tim etik juga dapat memberikan pendampingan kepada sivitas akademik dalam proses penelitian hingga publikasi peneilitian. Kontribusi lain perpustakaan dapat berperan menjadi pihak yang independent dalam melakukan pemeriksaan jika terdapat dugaan pelanggaran kode etik ilmiah.

\section{b. Program Literasi Informasi Terintregasi Pada Kurikulum Perkuliahan}

Pada Perguruan Tinggi baik negeri maupun swasta, program literasi biasanya menjadi program perpustakaan, dan tidak menjadi program wajib kampus. Padahal dalam pendidikan tinggi kemampuan penelusuran dan penggunaan informasi yang efektif dan etis mutlak dimiliki sivitas akademik yang berguna dalam pembelajaran, penelitian hingga pemebelajaran sepanjang hayat. Pembekalan kemampuan pencarain, penggunaan dan evaluasi informasi ini terkonsep pada program literasi yang akan berjalan efektif jika dilaksanakan secara sistematis dan terstruktur.

Literasi informasi (melek informasi) menurut American Library Association (ALA) (2000) adalah satu rangkaian kemampuan individu untuk mengenali informasi saat diperlukan dan memiliki kemampuan untuk menemukan, mengevaluasi, dan menggunakan informasi tersebut secara efektif. ${ }^{10}$ Standar literasi informasi untuk perguruan tinggi telah diteliti oleh Tirado dan Muñoz yang merekomendasikan 7 standar yang diadopsi dari model literasi dari 3 negara yaitu United States, Inggris, Australia, dan Norwegia. Adapun 7 standar literasi informasi untuk Perguruan tinggi yaitu:

\footnotetext{
${ }^{10}$ American Library Association. “The Information Literacy Competency Standards for Higher Education.” 2000. https://alair.ala.org/handle/11213/7668
} 
1. Kemampuan mendefinisikan dan mengetahui kebutuhan informasi

2. Mengetahui dimana harus mencari informasi

3. Penilaian informasi

4. Kemampuan mengorganisasikan informasi

5. Penggunaan informasi

6. Kemampuan mengkomunikasikan informasi dan etika penggunaan informasi

7. Evaluasi atau penilaian terhadap proses pencarian dan informasi yang ditemukan $^{11}$

Pada tahapan literasi di atas, selain mencari informasi, seorang yang literat juga terlihat pada sikap penggunaan informasi yang etis. Etika penggunan informasi disini termasuk pada kejujuran dalam menggunakan informasi dengan memperhatikan kutipan sumber informasi yang dirujuk. Kebiasaan ini perlu dihimbau sejak awal perkuliahan sebagai modal awal dalam penulisan makalah perkuliahan maupun penulisan karya ilmiah lainnya. Pembekalan literasi informasi yang diintegrasikan kedalam perkuliahan akan menambah kesadaran pentingnya nilai-nilai integritas akademik mahasiswa sejak dini. Pihak perpustakaan dapat melakukan pendekatan dengan pihak fakultas atau bagian akademik untuk menyusun kurikulum yang memuat pelatihan literasi informasi, seperti pada mata kuliah Bahasa Indonesia, atau Metodologi Penelitian. Materi pembelajaran dapat diintegrasikan dengan materi penulisan ilmiah, yang dapat berjalan paralel sebagai dasar sebelum mahasiswa melakukan penelitian. Selain itu edukasi mengenai bagaimana mencegah plagiat dapat dipresentasikan untuk meningkatkan kesadaran mahasiswa tentang pentingnya menghargai karya orang lain.

${ }^{11}$ Alejandro Uribe Tirado dan Wilson Castaño Muñoz, "Information Literacy Competency Standards for Higher Education and their Correlation with the Cycle of Knowledge Generation" Liber Quarterly Volume 22 Issue 3, (2012): 213-239. DOI: 10.18352/lq.8167 


\section{c. Kebijakan tentang Pencegahan Plagiat}

Langkah preventif pencegahan tindakan plagiat dapat dilakukan dengan menerapkan kebijkan-kebijakan yang mengatur adanya pencegahan tindakan plagiat bagi seluruh sivitas akademik. Amanah pentingnya penanggulangan plagiat telah tercantum dalam Peraturan Menteri Pendidikan Nasional No. 17 Tahun 2010 tentang pencegahan plagiat di perguruan tinggi dimana setiap karya ilmiah yang dihasilkan di lingkungan perguruan tinggi harus dilampirkan pernyataan bebas plagiat, sehingga jika terjadi gugatan dimasa yang akan datang penulis akan menerima sanksi dari peraturan perundang undangn yang berlaku. Selain itu, terdapat ketentuan bahwa semua karya ilmiah wajib diunggah secara elektronik melalui portal Garuda (Garba Rujukan Digital) sebagai titik akses terhadap karya ilmiah mahasiswa/dosen/peneliti/tenaga kependidikan Indonesia, atau portal lain yang ditetapkan oleh Direktur Jenderal Pendidikan Tinggi. ${ }^{12}$ Kebijakan keterbukaan akses karya ilmiah secara online menjadi angin segar, yang memudahkan seorang peneliti mendapat hak cipta dari karya ilmiah yang dipublikasi. Orisinalitas sebuah karya ilmiah akan terlihat kepada pihak yang paling pertama mengunggah di internet.

Kebijakan lain dapat diterapkan pada Perguruan Tinggi yang sudah menggunakan alat deteksi plagiat, yaitu dengan menentukan batas maksimum presentase kemiripan suatu dokumen sebelum publikasi ilmiah. Standar ini dapat ditentukan sesuai dengan kesepakatan fakultas dan pimpinan terkait. Kebijakan ini diharapkan menjadi tolak ukur standar tingkat kemiripan suatu karya ilmiah dengan yang sudah diuploud di internet.

Kebijakan strategis lainnya dapat diupayakan Perpustakan dengan bekerjasama dengan bagian Program Studi untuk mewajibkan mahasiswa yang akan mengikuti sidang proposal tugas akhir untuk mengikuti program sertifikasi literasi informasi dari perpustakaan. Sertifikasi literasi informasi bagi mahasiswa menjadi edukasi praktis akan pentingnya etika penggunaan informasi dan cara mensitasi sebagai bentuk integritas seorang akademisi.

${ }^{12}$ Peraturan Menteri Pendidikan Nasional Nomor 17 Tahun 2010 tentang Pencegahan dan Penaggulangan Plagiat di Perguruan Tinggi, Menteri Pendidikan Nasional (Jakarta, 2010). 


\section{d. Sosialisasi Anti Plagiarisme}

Upaya pemberantasan plagiat menjadi tanggung jawab moral pepustakaan dalam menjalankan tugas dan fungsinya. Sosialisasi anti plagiat dapat dimulai dari orientasi mahasiswa baru, mengenai aspek-aspek praktis tindakan plagiat. Mahasiswa baru yang terbiasa dengan sistem pembelajaran dari sekolah seringkali tidak mengetahui apa yang dimaksud plagiarisme secara praktis. Pemahaman plagiat biasanya ketika seseorang menjiplak seluruh karya dari orang lain dan diakui sebagai karya pribadi, padahal praktek plagiat memiliki jenis yang beragam. Masalah pengutipan dan penggunaan data penelitian yang valid perlu diketahui mahasiswa agar mereka tidak terjebak dalam tindakan plagiat secara tidak sengaja. Selain mahasiswa, sosialisasi juga perlu diberikan kepada dosen yang memiliki kewajiban melakukan publikasi ilmiah untuk menaikkan jenjang jabatan fungsional. Pemahaman plagiat yang komprehensif sangat perlu dimiliki oleh dosen agar produk riset yang mereka hasilkan benar-benar memenuhi standar karya ilmiah dan etis. Sosialisasi yang dikemas dalam bentuk kegiatan workshop menarik diselenggarakan dengan materi-materi yang langsung dapat diimpliksikan seperti workshop penggunaan e-resources, penggunaan Reference Management Tools, seperti Mendeley, Zetero, Endnote, dan penggunaan alat deteksi plagiat seperti Turnitin, iThenticate, dan PlagScan. Perpustakaan diharapkan mampu berperan secara kreatif melakukan kegiatan-kegiatan sosialisasi yang sesuai kebutuhan mahasiswa dan dosen.

\section{e. Penggunaan Alat Pencegah Plagiat}

Tindakan plagiat secara kasat mata dapat dilihat dari kesamaan kata demi kata yang diambil dari tulisan orang lain tanpa mencantumkan sumbernya. Antisipasi untuk mengetahui hal ini dapat dilihat melalui alat deteksi plagiat yang berupa database anti plagiat. Terdapat beberapa alat deteksi plagiat yang cukup banyak digunakan di perguruan tinggi seperti: Turnitin, iThanticate, PlagScan dll. Sistem kerja alat ini adalah memproses kesamaan kata demi kata dengan dokumen yang ada di internet. Alat ini langsung bekerja dengan memberi highlight pada kalimat yang sama pada 
sumber yang ada di internet. Jumlah presentase dari setiap sumber akan berbeda-beda tergantung seberapa banyak tulisan yang sama. Pengutipan yang benar juga diperlukan dalam penggunaakan alat ini, karena pengutipan yang tidak mengikuti gaya selingkung yang benar akan rentan terdeteksi plagiat. Kemampuan deteksi plagiat pada alat ini dapat digunakan sebagai pencegahan yang cukup efektif dalam waktu jangka pendek. Saat ini kelemahan alat deteksi plagiat, tidak dapat mendeteksi karya ilmiah dengan bahasa yang sudah di pharaprase atau diterjemahkan dengan bahasa yang berbeda. Sehingga alat pencegah plagiat seperti ini hanya sebagai bantuan sementara dan tidak dapat menumpas adanya mental plagiator secara utuh dalam rangka mewujudkan integritas akademik yang kokoh.

\section{f. Menyediakan Koleksi yang Memadai}

Maraknya tindakan plagiat oleh mahasiswa patut mejadi bahan perenungan baik dari sistem pembelajaran maupun perpustakaan sebagai penyedia ilmu pengetahuan. Perpustakaan perguruan tinggi wajib menyediakan koleksi baik tercetak maupun elektronik yang berkualitas untuk menunjang pendidikan, penelitian dan pengabdian masyarakat. Menurut Cahyono, terdapat beberapa indikator standar koleksi perpustakaan perguruan tinggi yaitu:

1. Perpustakaan menyediakan akses terhadap koleksi sesuai dengan bidang penelitian, inti kurikulum, atau keunggulan institusi.

2. Perpustakaan menyediakan koleksi dalam berbagai bentuk/format yang dapat diakses secara fisik dan virtual.

3. Perpustakaan membangun dan memastikan akses terhadap koleksi langka/unik, termasuk koleksi digitalnya.

4. Perpustakaan memiliki infrastruktur untuk mengumpulkan, mengorganisasikan, menyediakan akses, mendiseminasikan, dan memelihara koleksi yang diperlukan oleh para pemustaka.

5. Perpustakaan mendidik pemustaka berkaitan dengan model ekonomis dan komunikatif. 
6. Perpustakaan memastikan akses jangka panjang terhadap temu balik koleksi. ${ }^{13}$

Perpustakaan dalam upaya menyediakan koleksi yang memadai harus mampu mengikuti perkembangan kebutuhan pemustaka dimana kecenderungan pemustaka saat ini menginginkan informasi yang mudah dan murah. Kemudahan pencarian pada Google seringkali menjerumuskan mahasiswa pada informasi-informasi yang tidak dapat dipertanggungjawabkan seperti pada Wikipedia, Wordpress, blogspot dll. Perpustakaan dapat mengambil alih peran google sebagai penyedia informasi yang tidak valid dengan menyediakan akses database yang kredibel. Layanan informasi berbasis online ini jauh akan lebih luas menjangkau mahasiswa dan dosen. Sumber referensi yang mumpuni akan membantu mahasiswa maupun dosen mendapatkan referensi yang benar-benar valid untuk mendukung sebuah kajian ilmiah sehinga terhindar dari perilaku plagiat.

\section{Penutupan}

Upaya perpustakaan dalam mewujudkan integritas akademik perlu dilakukan berkesinambungan dan bersinergi dengan seluruh unit supaya kejujuran akademik menjadi budaya sivitas akademik di perguruan tinggi. Pencegahan tindakan plagiat menjadi awal dari upaya menumbuhkan kejujuran dengan tidak mudah mengambil hak orang lain untuk kepentingan pribadi. Hal ini akan mendidik mahasiswa memiliki jiwa berintegritas tinggi yang dampaknya akan dirasakan hingga terjun ke dunia kerja, dimana kelak mereka menjadi penerus bangsa yang memiliki jiwa tidak mudah korupsi dalam bentuk materiil maupun waktu. Upaya yang dapat dilakukan perpustakaan dalam meningkatkan integritas akademik antara lain: pembentukan tim etika, integrasi program literasi informasi kedalam kurikulum, kebijakan pencegahan tindakan plagiat, sosialisasi anti plagiat, penggunaan alat deteksi plagiat dan penyediaan referensi yang memadai.

${ }^{13}$ Teguh Yudi Cahyono, "Standar Nasional Perpustakaan Perguruan Tinggi," Library Universitas Negeri Malang, Juli 2017. http://lib.um.ac.id/wp-content/uploads/2017/07/StandarNasional-Perpustakaan-Perguruan-Tinggi.pdf 
Pemberantasan disintegritas perlu mengedepankan investigasi secara objektif seluruh pihak agar kejujuran akademik benar benar dapat ditegakkan tanpa memandang bulu.

\section{Daftar Pustaka}

American Library Association. "The Information Literacy Competency Standards for Higher Education.” 2000. https://alair.ala.org/ handle/11213/7668

Arinda, Fiska Puspa, "Ketidakjujuran Akademik Mahasiswa Perguruan Tinggi X di Surakarta”, Skripsi, Universitas Muhammadiyah Surakarta, 2015. http://eprints.ums.ac.id/34416/1/02.\%20NASKAH\%20 PUBLIKASI.pdf

Buchori, Sahril, Muhammad Ibrahim, dan Abdul Saman. "Pengaruh Character Education Training melalui Outbound Training untuk Peningkatan Kejujuran dan Integritas," Jurnal Psikologi Pendidikan \& Konseling Vol. 2 No. 1 (2016): 12-19. https://ojs.unm.ac.id/JPPK/ article/view/2089

Cahyono, Teguh Yudi, "Standar Nasional Perpustakaan Perguruan Tinggi," Library Universitas Negeri Malang, Juli 2017. http://lib.um.ac.id/ wp-content/uploads/2017/07/Standar-Nasional-PerpustakaanPerguruan-Tinggi.pdf

International Center for Academic Integrity. The Fundamental Values of Academic Integrity. Illinois: Clemson University, 2013. https:// academicintegrity.org/fundamental-values/

Jones, Lars R. Academic Integrity \& Academic Dishonesty: A Handbook About Cheating \& Plagiarism. Florida: Floride Institude of Technology, 2011. http://hdl.handle.net/11141/2601.

Kamus Besar Bahasa Indonesia, "Integritas," akses 14 November 2019 https:// kbbi.web.id/integritas

Menteri Pendidikan Nasional. Peraturan Menteri Pendidikan Nasional Nomor 17 Tahun 2010 tentang Pencegahan dan Penaggulangan Plagiat di 
Perguruan Tinggi, Jakarta, 2010.

Menteri Riset, Teknologi, Dan Pendidikan Tinggi. Peraturan Menteri Ristek Dikti Nomor 54 tahun 2016. Jakarta, 2016.

Rohmanu, Abid, “Tata Kelola Mahasiswa Terhadap Integritas Akademik dan Plagiarisme," Muslim Heritage Vol. 1 No. 2 (2016): 335. http://jurnal. iainponorogo.ac.id/index.php/muslimheritage/article/view/603

Tirado, Alejandro Uribe dan Wilson Castaño Muñoz, "Information Literacy Competency Standards for Higher Education and their Correlation with the Cycle of Knowledge Generation” Liber Quarterly Vol. 22 Issue 3, (2012): 213-239. DOI: 10.18352/lq.8167

Wibowo, Adik, "Mencegah dan Menanggulangi Plagiarisme di Dunia Pendidikan," Jurnal Kesehatan Masyarakat Nasional, Vol. 6 No. 1 (2012): 195-200. http://journal.fkm.ui.ac.id/kesmas/article/ view/84/85 